\title{
ANAEROBIC DIGESTION OF SEWAGE SLUDGE MIXTURE FOR THE REDUCTION OF INDICATOR AND PATHOGENIC MICROORGANISMS
}

\author{
Ram Chandra Poudel*, Dev Raj Joshi**, Nawa Raj Dhakal*** and Amrit Bahadur Karki**** \\ * Department of Microbiology, National College, Khusubi, Kathmandu, Nepal. \\ **Central Department of Microbiology, Kirtipur, Kathmandu, Nepal. \\ ***Alternative Energy Promotion Centre, Khumaltar, Lalitpur, Nepal. \\ **** Yashoda Sustainable Development Pvt. Ltd.
}

\begin{abstract}
Anaerobic digestion is a technique used for the sanitizing the sewage sludge before its final disposal. We determined the fate of indicators and pathogens in sewage sludge mixture subjected to mesophilic anaerobic digestion (MAD) and ambient anaerobic digestion (AAD) for 30 and 35 days respectively by culture based microbiological methods (bacteria) and formal-ether sedimentation technique (parasites). While monitoring the organisms at five days intervals, MAD effectively reduced most of the bacteria and parasites to undetectable levels than AAD. Interestingly, the highest reductions in load were observed for faecal coliforms (5.16 $\left.\log _{10} \mathrm{cfu} / \mathrm{ml}\right)$ in the sewage sludge mixture of MAD which met the class A biosolid standard (USEPA). Like wise, the bacterial load reductions were negatively correlated and statistically significant $(p<0.005)$ with days of both digestions and the relation between total coliforms load and days of MAD experienced higher correlation coefficient ( $r=-0.992)$ and $\mathrm{R}^{2}(0.984)$ values which shows higher validity in regression model. Therefore, MAD can be considered as a promising method for reduction of indicator and pathogenic microorganisms in sewage sludge mixture.
\end{abstract}

Keywords: Anaerobic digestion; Correlation coefficient; Regression model; Sewage sludge.

\section{INTRODUCTION}

Sewage sludge acts as the reservoir of several indicator and pathogenic microorganisms (Arthurson, 2008; Saleem et al., 2001). However, its utilisation in agricultural production has been gaining increasing interest in recent years (Stone et al., 1998). It is therefore, very important to control pathogens present in sewage sludge for protection of humans, animals and plants (Lepeuple et al., 2004).

The reduction of indicators and pathogens in sludge is influenced by the treatment methods used to stabilize it in sewage treatment plants (Carrington, 2001). Anaerobic digestion is an appropriate technique for the treatment of sludge before final disposal (Sahlström et al., 2004); the disinfection degree of which is influenced by a variety of interacting operational variables and conditions but it is highly dependent on time and temperature (Maier et al., 2006). It can be performed at thermophilic $\left(50-60^{\circ} \mathrm{C}\right)$, mesophilic (30$\left.38^{\circ} \mathrm{C}\right)$ or psychrophilic conditions $\left(<20^{\circ} \mathrm{C}\right)$ though mesophilic anaerobic digestion (MAD) is a quite common because of the stability of the process (Horan et al., 2004). From the perspective of health, USEPA has classified the treated sludge i.e. biosolid into two classes: class A and class B. In order to meet Class A and Class B biosolid standards, the treated sludge (biosolid) must have a faecal coliform count of less than 1000 and two million MPN per gram of dry sludge respectively (Stout, 2002).

A diverse group of pathogens present in the sewage sludge pose serious threat to human and animal health. Therefore, in this study, we determined the occurrence of microorganisms, in particular indicator and pathogenic microorganisms in sewage sludge mixture and evaluated the fate of selective microorganisms in mesophilic and ambient anaerobic digestion of sewage sludge mixture.

\section{MATERIALS AND METHODS}

\section{Sampling and Digestion of sewage sludge mixture}

Sewage sludge was collected from sewerage treatment plant, Guheshwori, Kathmandu by random sampling technique which was then, mixed with about one kg of cow dung and tap water was added to mix the contents homogenously. Thus formed sewage sludge mixture was divided into two equal parts and fed into two similar laboratory model biodigester of

Author for Correspondence: Ram Chandra Poudel, Department of Microbiology, National College, Khusubi, Kathmandu, Nepal, E-mail: ramchpd5@yahoo.com. 
capacity 5 liters up to $3 \backslash 4^{\text {th }}$ of the total volume. One digester was left at ambient temperature $\left(10-20^{\circ} \mathrm{C}\right)$ while the temperature of other digester was maintained at mesophilic temperature $\left(35 \pm 2{ }^{\circ} \mathrm{C}\right)$ by keeping it in the water bath. The mixture was mixed two times daily by manual shaking to use the whole digester contents for digestion. The schematic diagram of laboratory model biodigester is shown in the figure 1. The laboratory setting was maintained at the Microbiology Laboratory of National College, Kathmandu. This study was carried out from October 2008 to January 2009.

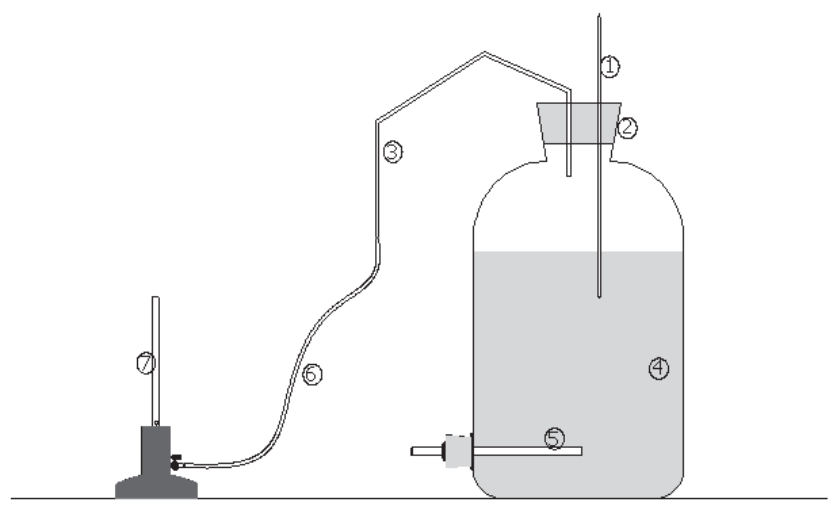

Figure1: Schematic diagram of laboratory model biodigester

(1) Thermometer, (2) cork, (3\& 5) glass tube, (4) sewage sludge mixture, (6) rubber pipe and (7) burner

\section{Microbial Analysis}

The initial day sample was taken just before feeding the sewage sludge mixture into the digester while the other well mixed samples were taken at 5 days intervals upto 30 and 35 days from batch type of AAD and MAD respectively. Each sample was divided into two parts for bacterial analysis and parasite detection. Diluted samples were used for bacterial analysis and spread on different microbiological media to isolate different bacteria: Plate count agar for total heterotrophic bacteria, M-Endo agar for total and faecal coliforms while Salmonella spp. and Shigella spp., Pseudomonas aeruginosa, Vibrio spp., Staphylococcus aureus and faecal Streptococci were enriched and isolated in their selective media. Conventional standard plate count method (APHA, 1998) was used for the enumeration of total heterotrophic bacteria and total and faecal coliforms and the average numbers of triplicate plates were reported (Cote et al. 2006; Benatti et al. 2002). All the isolated bacteria were identified by their cultural, morphological and biochemical characteristics. Similarly, the protozoa and helminths were detected by formal-ether sedimentation technique (Ridley and Hawgood, 1995).

\section{Data Analysis}

Statistical analysis of the data was performed by SPSS (version 11.5). The one way ANOVA test was applied to observe any significant relationships among the variables and 95\% confidence interval was considered significance. The regression model was applied between bacterial load and days of anaerobic digestion variables.

\section{RESULTS AND DISCUSSION}

Sewage sludge may harbor diverse type of pathogenic and indicator organisms (Benatti et al., 2002; Saleem et al., 2001). Altogether 22 bacteria belonging to eight genera: Escherichia coli, Citrobacter frundii, Pseudomonas aeruginosa, Proteus vulgaris, Salmonella spp., Shigella spp., Staphylococcus aureus and Enterococcus spp. were isolated and four different species of parasites: Giardia lamblia, Entamoeba histolytica, Ascaris lumbricoides and Hymenolepis nana were detected from sewage sludge mixture. Lepeuple et al. (2004); Benatti et al. (2002); Carrington (2001); Strauch (1998) and Dudley et al. (1980) have reported similar genera of bacteria and parasites from the sewage sludge. However, the levels and diversity of pathogens in sewage sludge vary depending on several factors including population size, local conditions, geographical location and seasonal variation (European Commission, 2001; Saleem et al., 2001).

The fate of monitored bacteria and parasites were found to be directly associated with time (days of digestion) and temperature (type of digestion) and the results are shown in the figure 2. The detection of Salmonella spp. was upto 15 and 10 days at ambient temperature and mesophilic temperature respectively which are in accordance with the findings of Côté et al. (2006); Kumar et al. (1999) and Gadre et al. (1986). Incidently, S. aureus and Pseudomonas aeruginosa

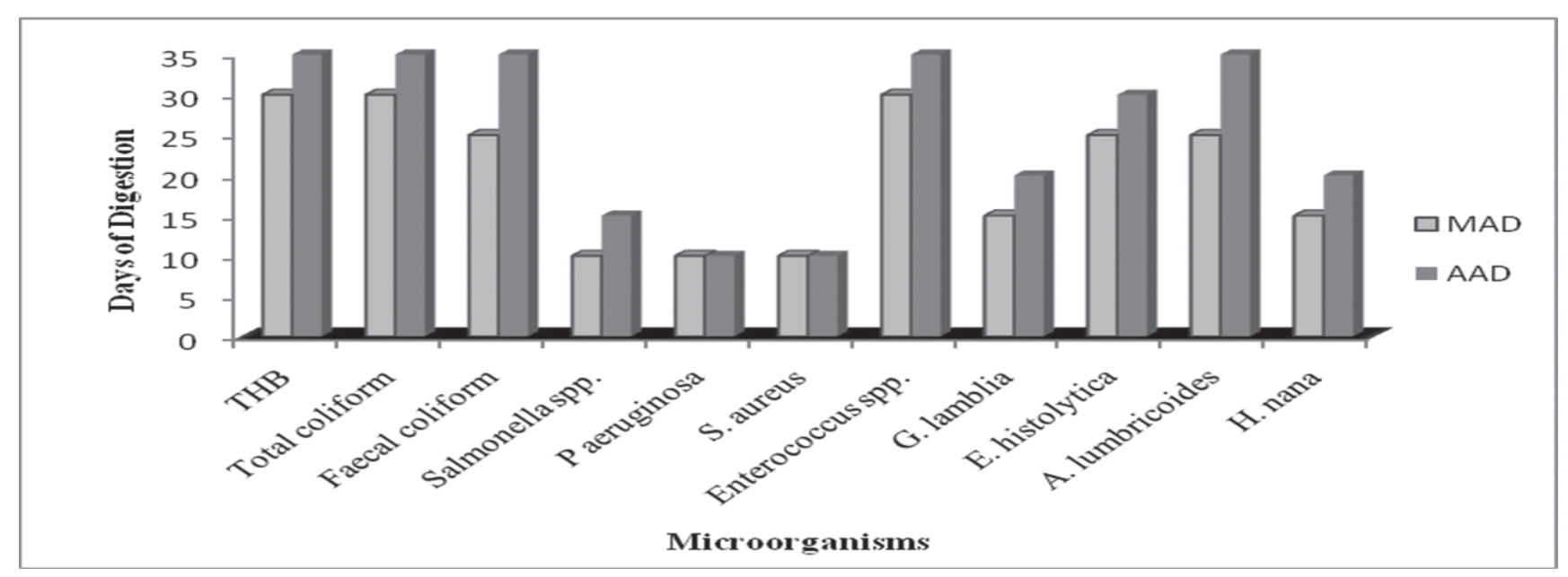

Note: THB- Total heterotrophic bacteria

Figure 2: Fate of microorganisms with digestion time and temperature 


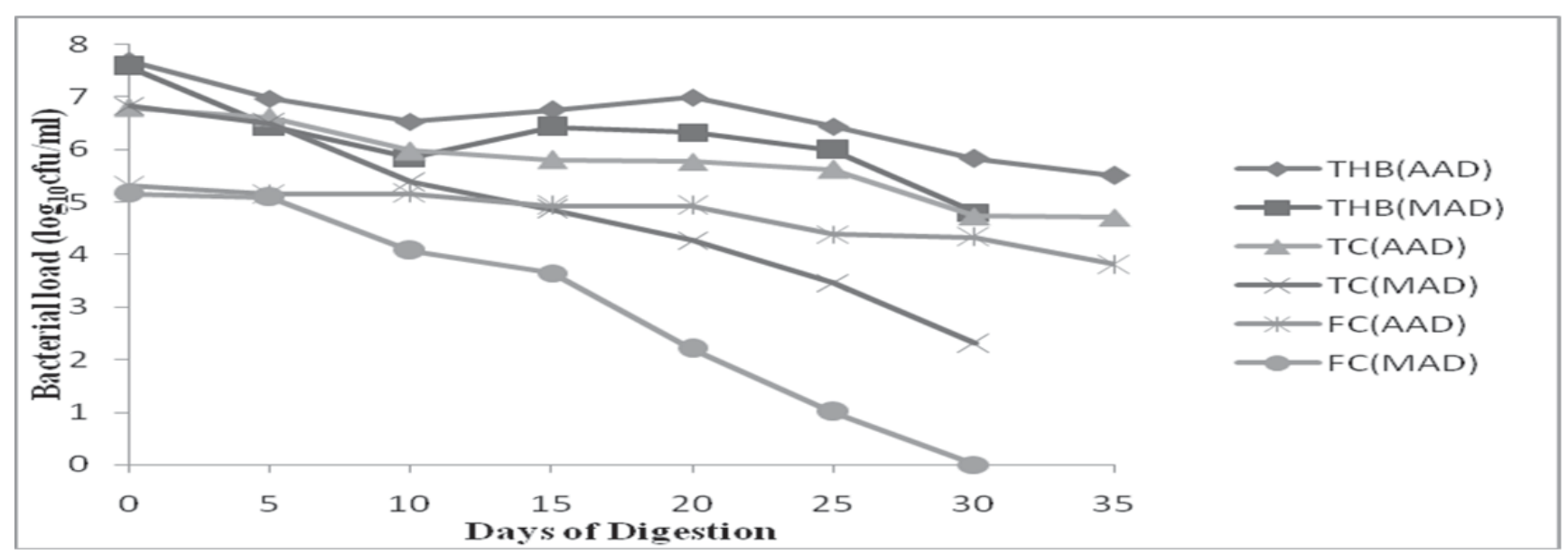

Note: Class $\mathrm{A}=3 \log _{10} \mathrm{cfu} / \mathrm{ml}$ and Class B= 6.3 $\log _{10} \mathrm{cfu} / \mathrm{ml}$

Figure 3: Total and faecal coliforms load in digesting sewage sludge mixture and comparison of load of faecal coliforms with USEPA standard

Table 1: Linear Regression of Bacterial Load $\left(\log _{10}\right)$ with Days of Digestion

\begin{tabular}{|l|l|l|l|l|l|}
\hline Bacteria & Digestion type & Correlation coefficient $(\mathrm{r})$ & Regression model & R square & p value (ANOVA) \\
\hline \multirow{2}{*}{ THB } & AAD & -0.890 & $\mathrm{y}=7.462-0.050 \mathrm{x}$ & 0.792 & 0.003 \\
\cline { 2 - 6 } & MAD & -0.812 & $\mathrm{y}=7.137-0.063 \mathrm{x}$ & 0.659 & 0.027 \\
\hline \multirow{2}{*}{$\begin{array}{l}\text { Total } \\
\text { Coliforms }\end{array}$} & AAD & -0.965 & $\mathrm{y}=6.797-0.060 \mathrm{x}$ & 0.931 & $<0.001$ \\
\cline { 2 - 7 } & $\mathrm{MAD}$ & -0.992 & $\mathrm{y}=7.020-0.148 \mathrm{x}$ & 0.984 & $<0.001$ \\
\hline $\begin{array}{l}\text { Faecal } \\
\text { Coliforms }\end{array}$ & AAD & -0.946 & $\mathrm{y}=5.449-0.040 \mathrm{x}$ & 0.895 & $<0.001$ \\
\cline { 2 - 7 } & MAD & -0.980 & $\mathrm{y}=5.758-0.182 \mathrm{x}$ & 0.961 & $<0.001$ \\
\hline
\end{tabular}

Note: THB- Total heterotrophic bacteria

were detected only upto 10 days in both the digestion process which might be due to their sensitiveness to anaerobic condition. Like wise, H. nana and G. lamblia were resulted in undetectable levels in 20 and 15 days of ambient and mesophilic anaerobic digestion respectively; the former results are supported by Benatti et al. (2002) and European Commission (2001). The destruction of parasite eggs and cysts is due to the lack of oxygen, increasing temperature and time during anaerobic digestion (Marchaim, 2007).

During monitoring the load of organisms at 5 days intervals, the load of total and faecal coliforms declined gradually in both digestions (figure 3). In mesophilic anaerobic digestion of sewage sludge mixture, the total heterotrophic bacteria, total coliforms and faecal coliforms were reduced by 2.78, 4.53 and $5.16 \log _{10}$ cfu/ml in 30 days. The faecal coliforms were below the detection level i.e. no growth was observed from $10^{-1}$ dilution which is similar to the result obtained by ElHadidi and Al-Turki (2007). Similar to our study, Ponugoti et $a l$, (1997) found upto $4 \log _{10}$ reduction for total coliforms in the sewage sludge subjected to MAD. In the digested sludge (biosolid) of AAD, 2.18, 2.11 and $2.53 \log _{10}$ reductions were achieved for total heterotrophic bacteria, total coliforms and faecal coliforms respectively in 35 days. In contrast to this result, Côté et al. (2006) achieved a highest of $5.47 \log _{10}$ reductions for coliforms in 20 days of anaerobically digested swine manure slurry at ambient temperature $\left(20^{\circ} \mathrm{C}\right)$. Of course, the lower reduction for coliforms found in this study is due to single batch digester used for digestion process unlike, sequencing batch digester used by Côté et al. (2006).
The load of faecal coliforms in sewage sludge subjected to MAD met the class A biosolid of USEPA standard i.e. $<3 \log _{10}$ MPN/g TS $\left(<3 \log _{10} \mathrm{cfu} / \mathrm{ml}\right)$ after 15 days. This might be due to the low initial load of the total and faecal coliforms in the sewage sludge mixture and co-digestion of sewage sludge with cowdung. The former reason is supported by Strauch (1991) who stated that the inactivation of pathogens is dependent on the initial amount of pathogens in the biowaste while the latter reason is supported by Côté et al. (2006) who found a higher reduction of faecal coliforms in the digested residue by mixing up swine slurry samples from different sources. The higher reduction of pathogens and indicators could be achieved by digesting the sewage sludge at higher temperature that is greater than mesophilic temperature.

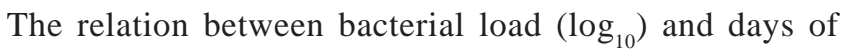
anaerobic digestion of sewage sludge mixture was found to be negatively correlated and statistically significant $(\mathrm{P}<0.005)$. Regression model are useful to predict the $\log _{10}$ reduction of indicators and pathogens. The high value of $\mathrm{R}^{2}$ i.e. 0.984 in mesophilic anaerobic digestion for total coliforms showed that about $98.4 \%$ of the data variability can be explained by the regression model. Moreover, the quantification of the relationship between days of digestion and bacterial load is shown in the table 1.

\section{CONCLUSION}

The degree of sanitization by anaerobic digestion was found to be directly dependent on time (days) and temperature and hence, mesophilic anaerobic digestion of sewage sludge 
mixture can be considered as a promising method for reduction of pathogenic and indicator microorganisms.

\section{ACKNOWLEDGEMENTS}

We wish to express our sincere gratitude to Biogas sector Partnership-Nepal (BSP-Nepal), Kathmandu for providing research grant and National College, Kathmandu for providing the laboratory facilities.

\section{REFERENCES}

American Public Health Association (APHA), American Water Works Association (AWWA) and Water Pollution Control Federation (WPCF). 1998. Standard methods for the examination for water and wastewater. $\left(20^{\text {th }}\right.$ edition), (Eds. L.S. Clescerl, A.E. Greenberg and A.D. Eaton) Washington, D.C., USA. ISBN: 0-87553-235-7

Arthurson, V. 2008. Proper Sanitization of Sewage Sludge: a Critical Issue for a Sustainable Society. Applied Environment Microbiology. 74(17): 5267-5275

Benatti, C.T., C.R.G. Tavares, B.P.D. Filho and Md. L.R. Moitinho. 2002. Operation of a Slow Rate Anaerobic Digester Treating Municipal Secondary Sludge. Electron. J. Biotechnol. 5(3): 216227

Carrington E.G. 2001. Evaluation of sludge treatments for pathogen reduction -Final report. WRc Ref: CO 5026/1, European Communities.

Côté, C., D.I. Massé and S. Quessy. 2006. Reduction of Indicator and Pathogenic Microorganisms by Psychrophilic Anaerobic Digestion in Swine Slurries. Bioresource Technology. 97: 686-691

Dudley, D.J., M.N. Guentzel, M.J. Ibarra, B.E. Moore and B.P. Sagik. 1980. Enumeration of potentially pathogenic bacteria from sewage sludges. Appl Environ Microbiol. 39(1): 118-126

European Commission. 2001. Evaluation of Sludge Treatments for Pathogen Reduction - Final Report for the European Commission Directorate-General Environment. (http://europa.eu.int)

El-Hadidi, Y.M. and A.I. Al-Turki. 2007. Organic fertilizer and biogas production from poultry wastes. Journal of Food, Agriculture \& Environment. 5(1): 228-233

Gadre, R.V., D.R. Ranade and S.H. Godbole. 1986. A note on survival of salmonellas during anaerobic digestion of cattle dung, Department of Microbiology, MACS Research Institute, Law College Road, Pune 411 004, India

Horan, N.J., L. Fletcher, S.M. Betmal, S.A. Wilks and C.W. Keevil.
2004. Die-off of enteric bacterial pathogens during mesophilic anaerobic digestion. Water Research. 38(5): 1113-1120.

Kumar, R., M.K. Gupta and S.S. Kanwar. 1999. Fate of bacterial pathogens in cattle dung slurry subjected to anaerobic digestion. Int. J. Environ. Health Res. 9 (2): 85-96.

Lepeuple, A.S., G. Gaval, M. Jovic and M.R. de Roubin. 2004. Literature review on levels of pathogens and their abatement in sludges, soil and treated biowaste. The Energy Research Centers of the Netherlands, WP3 Hygienic Parameters, Horizontal Project. Retrieved from www.ecn.nl/docs/society/horizontal/hor6_ pathogens.pdf

Maier, R.M., I.L. Pepper and C.P. Gerba. 2006. Environmental Microbiology, Elsevier Publishers, ISBN: 0-12-497570-4, USA: 505-520

Marchaim, U. 2007. Biogas processes for sustainable development. http://www.fao.org/docrep

Ponugoti, P.R., M.F. Dahab, and R. Surampalli. 1997. Effects of different biosolids treatment systems on pathogen and pathogen indicator reduction. Water Environ. Res. 69: 1195-1206.

Ridley, D.S. and B.C. Hawgood. 1995. The value of formal-ether concentration of fecal cysts and ova. Journal of Clinical Pathology. 9: 14-16.

Saleem, M., M.H. Al-Malack, and A.A. Bukhari. 2001. Seasonal variations in the microbial population density present in biological sludge. Environ. Technol. 22: 255-259

Sahlström, L., A. Aspana, E. Baggea, M.L. Danielsson- Thamb and A. Albihna. 2004. Bacterial pathogen incidences in sludge from Swedish sewage treatment plants. Water Research. 38: 1989-1994

Strauch, D. 1998. Pathogenic Micro-organisms in Sludge - Anaerobic Digestion and disinfection Methods to Make Sludge Usable as Fertilizer. European Water Management. 1(2): 12-26.

Strauch, D. 1991. Survival of Pathogenic Microorganisms and Parasites in Excreta, Manure and Sewage Sludge. Rev. Sci. Tech. Off. Int. Epiz. 10(3): 813-846.

Stone, R.J., E.I. Ekwue and R.O. Clarke. 1998. Engineering properties of sewage sludge in Trinidad. Journal of Agricultural Engineering Research. 70: 221-230.

Stout, J.K. 2002. Sludge Management in Alfenas, Brazil.M.E. Dissertation Submitted to the Department of Civil and Environmental Engineering at the Massachusetts Institute of Technology (Brazil). 